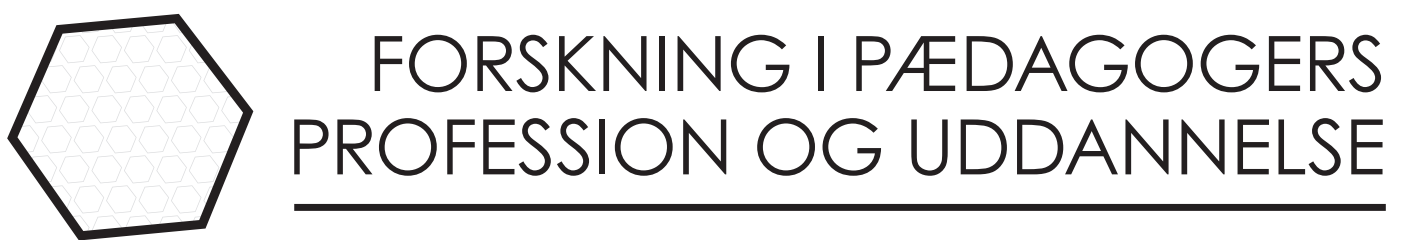

\title{
Poedagogisk ekspertise og kvalitet i fritidsinstitutionerne
}

\section{Mette Høgh Stcehr}

Cand.mag. i etnografi og socialantropologi. Uddannelsesleder

Pædagoguddannelsen, Professionshøjskolen Absalon

mets@pha.dk

\section{Lisbeth Madsen}

Cand.scient.anth. Lektor v. Videreuddannelse,

Københavns Professionshøjskole

lbma@kp.dk 


\section{Resume}

Det pædagogiske arbejde med børn og unge i fritidsinstitutionerne har de senere år politisk, økonomisk, kompetenceudviklingsmæssigt og forskningsmæssigt været nedprioriteret til trods for institutionernes samfundsmæssige rolle og betydning for børn og unge. Denne artikel diskuterer, hvilken betydning dette har for den faglige ekspertise på området. Gennem analyse af empiri indsamlet i forbindelse med et projekt vedrørende kompetenceudvikling på det fritidspædagogiske område, beskriver artiklen den faglige udvikling i praksis, hvilken viden henholdsvis pædagoger, ledere og organisationer fremhæver som essentiel, hvad dette kan være et udtryk for, og hvorfor netop denne viden sættes i tæet relation til drøftelser vedrørende pædagogisk ekspertise samt kvalitet i fritidsinstitutionerne. Med afsæt i analyser fra en gennemført undersøgelse er artiklens pointe, at pædagogisk kvalitet i fritidsinstitutionerne tager udgangspunkt i pædagogfaglig viden og situationsbunden kundskab om børne- og ungegruppers divergerende hverdagsliv, institutionsliv og interessefællesskaber.

\section{Abstract \\ Pedagogical expertise and quality in leisure institutions}

Within the last few years social pedagogical work among children and young people in after school clubs and -centers have not been prioritized politically and economically, with regard to continuing education and when it comes to research despite the societal role and importance these institutions have for the development of children and young people. The article discusses the possible consequences this has had for professional expertise in the field through an analysis of empirical data collected in relation to the project: 'development of professional courses to professionals working within the field of after school clubs and centres.' The article takes the reader through a description of the field within the last few years to an analysis of the knowledge that pedagogues, leaders and various organizations evaluate as needed. We will point out that good quality must be found in the relation between knowledge on the one side and capable professionals on the other.

\section{Nøgleord}

fritidspædagogik, pædagogisk ekspertise, pædagogisk kvalitet, pædagogisk arbejde i fritid og skole.

\section{Keywords}

Leisure pedagogy, pedagogical expertise, pedagogical quality, pedagogical work in leisure and school. 


\section{Indledning}

Denne artikel tager afsæt i projektet Udvikling af fagspecifikke kurser for medarbejdere og ledere på det fritidspædagogiske område, der er finansieret af Udviklings- og forskningsministeriets pulje til Voksen- og efteruddannelsesprojekter (VEU-puljen) (Madsen og Stæhr, 2020). Projektet blev afsluttet i december 2019 og havde til formål at afsøge om og hvordan, kurser på efter- og videreuddannelsesniveau modsvarer de aktuelle behov for kompetenceudvikling inden for det fritidspædagogiske område. I projektet gennemførte vi en undersøgelse, der gav et detaljeret indblik i muligheder og barrierer, som medarbejdere og ledere i fritidsinstitutionerne oplever, de møder i deres pædagogiske arbejde. Den metodologiske interesse i projektet har været generering af empiri gennem inddragelse og deltagelse af pædagoger, ledere og interesseorganisationer. Undersøgelsen udgør vores empiriske materiale, og det er med udgangspunkt i den, at vi ønsker at diskutere, hvorvidt et manglende politisk, forskningsmæssigt og økonomisk fokus har haft betydning for det fritidspædagogiske område og den faglige ekspertise inden for området.

Som beskrevet andre steder har de fritidspædagogiske institutioner og deres pædagogiske medarbejdere igennem de sidste seks år været i en forandringsproces, som har gjort det vanskeligt i praksis at udfolde og fastholde en fritidspædagogisk faglighed (Ringskou og Gravesen, 2019; Højholt, Kousholt \& Stanek, 2014; Stæhr og Ankerstjerne, 2017, 2019; Tofteng og Madsen, 2017; Petersen og Feilberg, 2015; Elvstrand og Lago, 2019). Undersøgelser og forskningsresultater fra feltet beskriver for eksempel på forskellig vis pædagogers oplevelse af, hvordan det pædagogiske arbejde i fritidsinstitutionerne politisk og økonomisk er blevet nedprioritereret og tilsvarende, hvordan deres pædagogiske faglighed i en skolekontekst og under nye vilkår kan bringes i spil. Midt i alt det nye og de mange nye samarbejdsrelationer har der ikke været plads til at udvikle den fritidspædagogiske praksis, og der har kun været meget få bidrag af ny forskningsbaseret viden inden for specifikt det fritidspædagogiske område (Ringskou og Gravesen, 2020). Ligeledes er der set et fald i andelen af ledere med en pædagoguddannelse i klubber og SFO'er (Kamp, 2019), og andre steder er lederne forsvundet til fordel for indskolingsledere, eller ledelsesopgaverne er lagt ud til pædagoger uden lederkompetencer (Kamp, 2019). Kombinationen af alt dette betyder, at pædagoger har en oplevelse af, at deres faglige ekspertise på det fritidspædagogiske område ikke er blevet hverken vedligeholdt eller udviklet.

For såvel praktikere, undervisere og forskere, der arbejder i og med det fritidspædagogiske felt, og som har fulgt de forandringer, feltet har været igennem siden skolereformen 2014, er det genkendeligt, at feltet er nedprioritereret økonomisk, politisk og kompetenceudviklingsmæssigt, men også forunderligt da vi samtidig i en politisk og samfundsmæssig kontekst genkender en stigende interesse for centrale fritidspædagogiske kernebegreber som eksempelvis demokrati, fællesskaber, medbestemmelse og dannelse (Brinkmann, 2017; Biesta, 2013; Biesta, 2018; 
Klafki, 2001; Stanek, 2019). Disse begreber er ikke forbeholdt det fritidspædagogiske område (jf. folkeskolens formålsparagraf), men det må antages, at man har mulighed for at arbejde med begreberne på andre måder i fritidsinstitutionerne end for eksempel i skolen, ligesom der i både forsknings- og udviklingsprojekter peges på fritidsinstitutionernes potentiale i forhold til at løfte vigtige socialpædagogiske opgaver, styrke arbejdet med børnefællesskaber, løfte børns trivsel med videre (Petersen, Sørensen, Sørensen \& Ladefoged, 2019; Ankerstjerne og Stæhr, 2018).

I denne artikel menes der med fritidspædagogik det pædagogiske arbejde, der har fokus på børns frie tid, som finder sted i tilknytning til fritidsinstitutioner; her afgrænset som SFO'er, klubber og fritidshjem, og hvor børn har medbestemmelse i forhold til, hvilke aktiviteter de vil tage del i, hvem de vil lege og være sammen med (Højholt, Kousholt \& Stanek, 2014; Ankerstjerne 2010; Elvstrand og Lago 2019). I vores optik kan det fritidspædagogiske arbejde således udgøres af mange forskellige former for aktiviteter, som anlægger et helhedsperspektiv på barnet, og giver dem mulighed for at udvikle sig sammen med andre. Ligeledes er begrebet faglig ekspertise et begreb, som kan være vanskeligt at afgrænse. I denne sammenhæng tager vi afsæt i BUPL's Pædagogiske Profil, hvori det beskrives, at "Pædagogers faglige ekspertise indebærer teoretisk og praktisk viden om børn og unges udvikling, leg, venskaber og konflikter. Den faglige ekspertise omfatter etiske overvejelser samt pædagogiske metoder og redskaber." (BUPL 2007, s7). Det centrale her er, at den faglige ekspertise forudsætter et teoretisk og praktisk vidensmæssigt afsæt, der løbende vedligeholdes, forstyrres og udvikles i interaktion med ny viden på området for eksempel i forbindelse med projekter eller kurser, som understøttes gennem fælles refleksioner.

Den empiriske undersøgelse som ligger til grund for artiklen peger, i tilknytning til denne afgrænsning af faglig ekspertise, på en række udtrykte behov for kompetenceudvikling samt argumentationer herfor, hvilket får os til at spørge, hvordan det står til med den faglige ekspertise inden for det fritidspædagogiske område. I forlængelse heraf er artiklens ærinde gennem materialet at diskutere det fritidspædagogiske arbejdes forskelligartede vilkår og betydningen af disse i forhold til en styrkelse af den faglige ekspertise på det fritidspædagogiske område.

Artiklen falder i tre dele. I første del præsenterer vi den empiriske undersøgelse og det metodiske design. I anden del kigger vi på, hvad betydningen af et manglende politisk, økonomisk, forskningsmæssigt og kompetenceudviklingsmæssigt fokus har betydet for den pædagogiske ekspertise på det fritidspædagogiske område. I tredje del diskuterer vi med afsæt i den empiriske undersøgelse mulige bud på, hvordan kvalitetsbegrebet kan anskues og inddrages i en fritidspædagogisk sammenhæng. 


\section{Metode og forskningsmcessig inspiration}

I forlængelse af skolereformen fra 2014 tildeles pædagoger en ny rolle i skolen, og de står i en ny virkelighed, hvor der mange steder har været væsentlige forandringer i vilkårene for det fritidspædagogiske arbejde (Aftaletekst, 2013). Der lægges nu mere vægt på samarbejdet med skolen og lærerne samt andre aktører om børnenes læring og trivsel. Det betyder også et fagligt fokusskift inden for efter- og videreuddannelse for pædagogernes vedkommende, og de seneste år har kompetenceudviklingen af medarbejdere i fritidsinstitutioner i højere grad været rettet mod pædagogers arbejde i skolen. Blandt andet har næsten 2000 pædagoger på landsplan taget diplommodulet Pædagogfaglighed og Læreprocesser; et modul hvis fokus var på pædagogers rolle og faglighed ind i skolen (Rambøll, 2019). Sideløbende har mange pædagoger deltaget i kompetenceudviklingsforløb sammen med lærere; blandt andet om læringsmålsstyret undervisning; it og medier, bevægelse med videre (Sauzet, 2019). Med afsæt i den udvikling blev projektet Udvikling af fagspecifikke kurser for medarbejdere og ledere på det fritidspædagogiske område til, hvori vi undersøgte kompetenceudviklingsbehov på det fritidspædagogiske område. Det er denne undersøgelses empiriske materiale, som ligger til grund for artiklen.

Undersøgelsen består af en kvalitativ undersøgelse, som udgøres af otte fokusgruppeinterviews med i alt 40 fritidspædagoger i seks institutioner fra seks forskellige sjællandske kommuner. Interviewene fulgte en spørgeguide, hvor vi spurgte ledelse og pædagogisk personale om, hvad de oplever som godt fritidspædagogisk arbejde, og hvad de oplever at mangle af faglig viden til at kunne styrke deres aktuelle fritidspædagogiske arbejde. Fokusgruppeinterviewene blev fulgt op af observationer i SFO'er og klubber samt mapping og interviews med godt 15 børn i samme seks institutioner. For det andet består undersøgelsen af en survey, der er udført af Professionshøjskolen Absalon og Københavns Professionshøjskole i samarbejde med BUPL. Survey'en er udsendt til 2500 pædagoger fra BUPL's medlemskartotek, som arbejder i det fritidspædagogiske felt. Heraf har 669 pædagoger besvaret skemaet, svarende til en svarprocent på $26,2 \%$. Spørgeskemaet, som giver os pejlinger på behov for kompetenceudvikling på det fritidspædagogiske område, er ikke fuldt repræsentativ, men giver et solidt fingerpeg til inspiration.

Projektets kvalitative og kvantitative undersøgelse kvalificerede projektets sidste og tredje del som bestod af dialogiske, analytiske processer med henholdsvis pædagoger, ledere af SFO'er og klubber samt repræsentanter fra faglige organisationer (herunder BUPL, Børne- og undervisningsministeriet, FOA, Ungdomsringen og KL). Der blev i alt afholdt tre analyseworkshops og to udviklingsworkshops, som havde karakter af dialogmøder. Metodisk er vi inspireret af dialogtraditionen, der har intention om at skabe forandringer, der er praksisorienterede og anvendelige på et konkret og lokalt plan (Toulmin og Gustavsen,1996). Ved metodisk at arbejde med dialogiske processer tilstræbte vi at skabe viden 
om oplevede behov for faglig udvikling på det fritidspædagogiske område gennem dialoger og aktivt samspil mellem repræsentanter fra professionshøjskolerne og faglige nøgleaktører fra feltet. Disse faglige nøgleaktører anses i projektet som personer med faglig ekspertise, der med hver deres positioner og perspektiver tilfører og er medskabere af viden på de afholdte workshops. Her blev analyserne løbende til gennem aktiv deltagelse i forhold til analyse af iagttagelser fra praksis (for eksempel ved præsentation af pointer fra den kvalitative og kvantitative undersøgelse), metarefleksive processer (for eksempel i mødet mellem ledernes og pædagogernes analytiske pointer eller vice versa) og kortlægning af muligheder for nye handlingstiltag. Deltagernes arbejde med at udvikle og drøfte analytiske pointer på workshoppene blev løbende dokumenteret gennem vægaviser, som efterfølgende blev en vigtig del af vores empiriske materiale.

I tillæg til undersøgelsens empiriske fund har vi undervejs ladet os inspirere forskningsmæssigt af den danske forskning inden for området (Højholt, Kousholt \& Stanek, 2014; Stanek, 2015; Stanek, 2019; Sauzet, 2019; Ringskou og Gravesen, 2019; Petersen, 2019; Görlich m.fl., 2019) samt nyere svensk forskning; for eksempel publikationen 'Fritidshemmets Möjligheter; at arbeta fritidspedagogiskt' (Elvstrand m.fl., 2019). Som i Danmark er forskningsfeltet inden for fritidspædagogik også i Sverige relativt begrænset, men i modsætning til andet international litteratur, så arbejder de i Sverige med en sammenlignende forståelse af det fritidspædagogiske arbejde.

\section{Fritidspaedagoger med faglig ekspertise - i skolen}

"Pædagogers ekspertise og faglighed afhænger af adgangen til forskningsbaseret viden. Faglighed og ekspertise vedligeholdes og udvikles gennem kontinuerlig adgang og pligt til efter- og videreuddannelse" (BUPL 2007, s. 7). Sådan afgrænses pædagogers faglighed og ekspertise i BUPL's Pædagogiske Profil. I dette afsnit udforsker vi, hvilke muligheder og barrierer et manglende politisk, forskningsmæssigt og økonomisk fokus har for den faglige ekspertise i det fritidspædagogiske felt, sådan som det træder frem i vores empiriske materiale. I vores analyse anvender vi ovenstående afgrænsning, idet vi anser kompetenceudvikling via efter- og videreuddannelse som et bidrag til at styrke pædagogers faglige ekspertise.

Først afdækkede vi om og hvor meget kompetenceudvikling, pædagogerne har fået inden for de seneste fem år, og dernæst undersøgte vi, hvilke videns- og fagområder pædagogerne er optaget af, og som de ønsker kompetenceudvikling inden for. Helt overordnet peger det kvantitative materiale på, at kompetenceudvikling rettet mod det fritidspædagogiske felt ikke er blevet prioriteret de seneste fem år. Tæt på halvdelen af de adspurgte pædagoger har således ikke deltaget i kurser inden for de seneste fem år, hvilket ses af tabel 1 nedenfor. 
Tabel 1 viser fordelingen af besvarelser på spørgsmålet: Hvor mange kortere kurser (af minimum 2 dages varighed) har du taget de seneste fem år inden for det fritidspcedagogiske område?
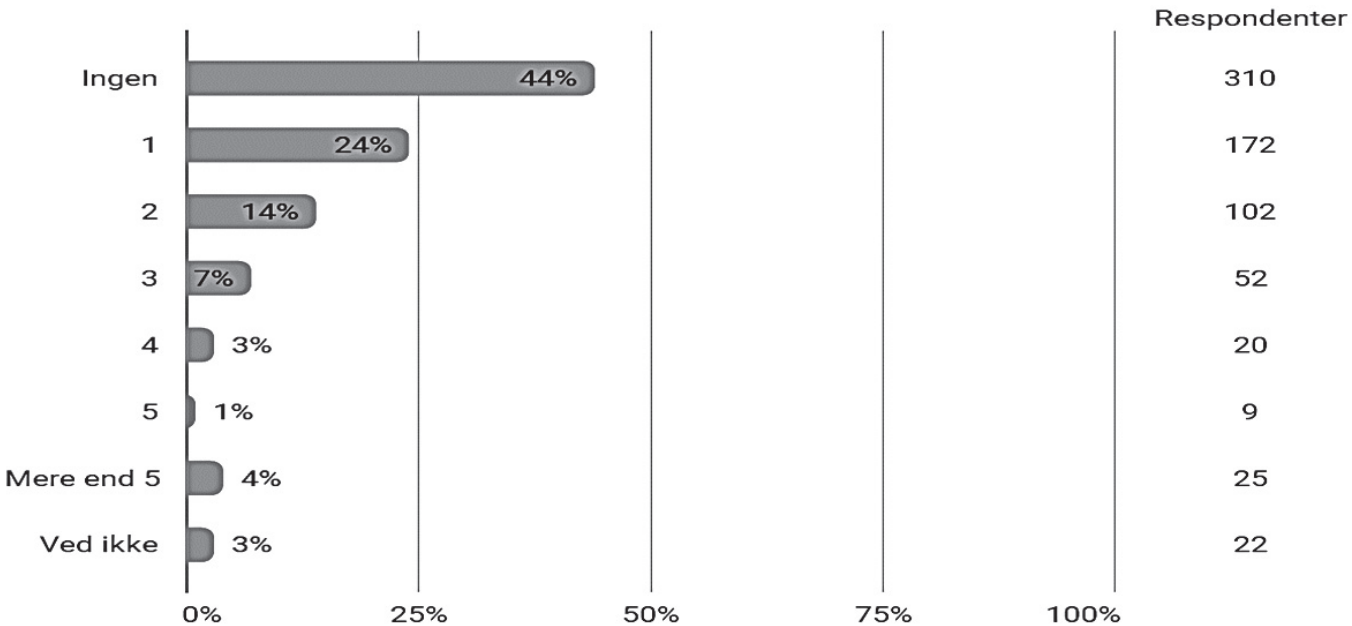

Tabel 1 (Madsen og Stcehr, 2020)

Som det fremgår af tabel 1 svarer 44 \% af de adspurgte, at de inden for det fritidspædagogiske område ikke har modtaget kurser de seneste fem år, mens 24 $\%$ svarer, at de har modtaget et kursus af minimum to dages varighed. $4 \%$ har modtaget mere end fem kurser.

I en række kvalitative svar fra spørgeskemaundersøgelsen uddyber respondenterne tillige, hvilke konkrete barrierer, de har mødt i forbindelse med at få kompetenceudvikling inden for det fritidspædagogiske område:

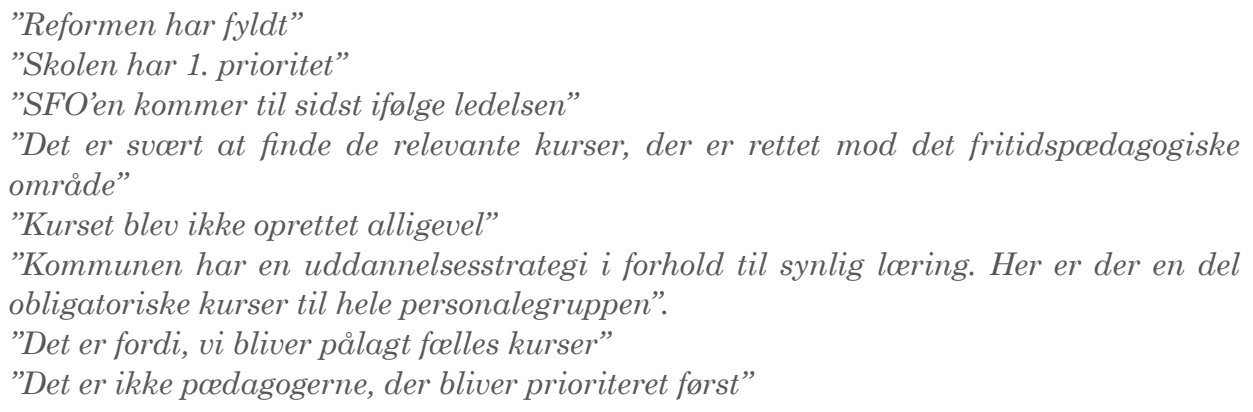

I ovenstående udsagn peger respondenterne på betingelser, der er koblet til politiske tiltag og ledelsesmæssige beslutninger, og som måske i særlig grad er knyttet til implementering af skolereformen i 2014.

I interviewene fra det kvalitative materiale spørger vi nærmere ind til dette, bl.a. ved at spørge til, hvilke faglige tematikker pædagogerne oplever, der skal til for at styrke deres fritidspædagogiske arbejde. Her udtrykte pædagogerne ønsker 
om at få mere viden om og herigennem få styrket deres faglighed især i forhold til temaer som udsathed, seksualitet, arbejdet med fællesskaber, trivsel og andre lignende temaer. En informant beskriver det sådan her: "Flere perspektiver på konkrete begreber fx fcellesskabsbegrebet - foellesskaber vedrører jo både venner, loeringsrum, interessefcellesskaber, frivillige, ufrivillige foellesskaber osv."

En anden udtrykker det således: "der er rigtig meget nyt inden for mobning. Det vil jeg gerne opdateres på.”

Mens en tredje taler ind i det nye udsatshedsbegreb: "Hvordan kan vi sikre, at vi har og arbejder med en dynamisk udsatshedsforståelse? Vi møder børn, der $i$ deres liv lever med mange forskellige former for livskriser fx skilsmisser og børns sorg, fx når forceldre dør eller blive syge."

Overordnet set peger det kvalitative materiale på, at det er en udbredt oplevelse blandt de interviewede pædagoger, at centrale begreber og essentielle vidensområder i den fritidspædagogiske faglighed - som fx deltagelse, demokrati og dannelse - ikke er blevet prioriteret, når det gælder kompetenceudvikling. I stedet er det tematikker, der er rettet mod en skolekontekst, der er blevet prioriteret og som i nogen grad opleves som en udvikling af en ny eller anden faglighed. Sauzet anvender begrebet mangeldiskurs som et billede på, hvordan kompetenceudviklingen de seneste fem år primært har handlet om, at pædagogerne skulle kompetenceudvikles inden for områder, de manglede i forhold til deres arbejde i skolen; fx klasseledelse, viden om læring og didaktik, facilitering af børn og unges læreprocesser med videre. Områder der i mindre grad bygger på traditionelle fritidspædagogiske kerneområder (Sauzet, 2019).

At den fritidspædagogiske faglighed står i skyggen af pædagogers arbejde ind i skolens kontekst, trådte endvidere frem i interviewmaterialet ved, at flere af de pædagoger som både arbejdede i skole og fritidsinstitutioner, havde svært ved at rette fokus mod det pædagogiske arbejde i fritidsinstitutionerne. I stedet berettede de oftere om deres arbejde i skolen. Vi spurgte dem for eksempel om, hvilke pædagogiske opmærksomhedsområder de arbejdede med i forhold til trivsel og fællesskab, og her var deres umiddelbare respons at fortælle om det pædagogiske arbejde med klassens trivsel fx ved oprettelses af ro i undervisningen og fællesskab i skoleregi - ikke som et arbejde udspændt mellem skoletid og tid i fritidsinstitutionen.

Som Stanek (2013) har beskrevet, så genkender vi i vores materiale, hvordan fritidspædagogikken forsvinder som opposition til skolen, når pædagogerne træder ind i skolen. Når det mere specifikt gælder fritidspædagogisk ekspertise, kan man måske spørge, om det blot står som opposition, eller om den fritidspædagogiske ekspertise måske snarere er på vej væk som fagligt fokusområde i en tid, hvor der er politisk og økonomisk fokus på "Tidlig indsats", "Barnets første 1000 dage" og pædagogers arbejde ind $i$ skolen. Eller er det et udtryk for, at pædagoger på 6 - 18 års området ikke skelner mellem, hvad der er særegent for henholdsvis fritidspædagogikken og skolepædagogikken, og at det betyder, at de netop overskrider skellet frem for at opretholde en for dem (måske) kunstig 
dikotomi mellem fritidspædagogik og skolepædagogik? En dikotomi, der måske ikke er meningsgivende i det daglige pædagogiske arbejde med børn og unge, der færdes og navigerer med adskillige skift mellem forskellige institutionelle arenaer. Igennem årene er dilemmaet i dette på forskellig vis blevet behandlet i litteraturen omkring pædagogers arbejde i fritid og skole (Broström, 2015; Richie og Tofteng, 2017; Petersen og Feilberg, 2015; Ankerstjerne og Stæhr, 2017). I de dialogiske processer på de afholdte workshops blev dikotomien mellem henholdsvis skolepædagogik og fritidspædagogik en analytisk opmærksomhed for os forskere, der derfor gjorde den til genstand for dialog på de efterfølgende workshops. Datamaterialet fra workshoppene viser, at dikotomien på den ene side skaber en uhensigtsmæssig skelnen mellem to konstruerede verdener, der fagligt set i hverdagen flyder sammen for pædagogerne, og på den anden side en skelnen som både praktikere, forskere, undervisere på professionshøjskoler, love og bekendtgørelser bidrager til at opretholde.

I det empiriske materiale og i dialogerne om det særegne ved henholdsvis fritidspædagogikken og skolepædagogikken, hvis man overhovedet kan tale om pædagogiske idiosynkrasier, blev det tydeligt inden for hvilke områder, praksisfeltet oplever at mangle faglig viden og faglig ekspertise. Pædagogerne giver således selv udtryk for en mangeldiskurs både i forhold til det pædagogiske arbejde i fritidsinstitutionerne og det pædagogiske arbejde i skolerne. I skolerne kommer manglerne til udtryk i forhold til at mangle viden om skolens logikker og undervisning, mens det i den fritidspædagogiske kontekst i højere grad handler om en manglende opdatering og styrkelse af den pædagogiske faglighed. Dette uddyber vi i næste afsnit.

\section{Ekspertise i fritidsinstitutionerne efterspørges}

I dette afsnit undersøger vi, hvilken viden pædagoger efterspørger og anser som vigtig i forhold til udviklingen af det pædagogiske arbejde i fritidsinstitutionerne. Som tidligere nævnt tager vi også her afsæt i den af BUPL formulerede pædagogiske profil (BUPL, 2007) i anvendelsen af begrebet ekspertise.

\footnotetext{
"Vi kunne godt toenke os at få mere viden om unge generelt. Så var der en $x$-generation og så y-generation. Men hvor er vi nu? Hvad er det for en ungekultur vi har i dag?"

"Da jeg gik på seminariet loeste vi Thomas Ziehe. Jeg savner ny og opdateret viden. Hvad loeser de nu?

"Vi har en specialafdeling på skolen. De fär hele tiden kurser inden for det specialpcedagogiske område. Men vi har jo de samme børn i SFO'en, men får ikke de samme kurser"
}

Ovenstående citater er nedslag fra vores empiriske materiale, som illustrerer to pointer når det gælder pædagogernes oplevelse af at udvikle og vedligeholde deres fritidspædagogiske ekspertise. For det første oplever de ikke at have opdateret viden i forhold til de børne- og ungegrupper, de arbejder med, hvorfor de efterspørger ny viden herom. Og for det andet oplever de, at det fritidspædagogiske felt er 
tilsidesat, mens de fagprofessionelle de samarbejder med, beskrives som nogen, der har nyeste relevante viden inden for aktuelle målgrupper. Materialet efterlader en eftertanke om, hvorvidt pædagogerne i det fritidspædagogiske felt grundet historiske og politiske diskurser samt økonomiske prioriteringer aktuelt er et underprioriteret område. En pointe der falder i fin tråd med en hovedpointe fra et nyt systematisk review, hvori forskningsbaseret litteratur inden for det skole- og fritidspædagogiske felt kortlægges (Ringskou og Gravesen, 2019, 2020). Her viser forfatterne, at indhold og prioriteringer i 68 udvalgte tekster fordeler sig inden for tekster om det tværprofessionelle samarbejde mellem lærere og pædagoger, samt 'beskrivelser af stereotyper, faghierarkier og forskelle mellem skolen (som lærerens domæne) og fritiden (som pædagogens traditionelle domæne)' (Ringskou og Gravesen, 2019, s. 80). Spørgsmålet er, hvad dette har betydet for kvaliteten og den faglige ekspertise inden for det fritidspædagogiske arbejde?

Vores analyser af det empiriske materiale peger på, at pædagogerne i nogen grad oplever at have mistet faglig ekspertise på det fritidspædagogiske felt. De giver blandt andet udtryk for, at de børne- og ungegrupper de arbejder med er meget forskelligartede, og at de i den forbindelse har behov for mere og nyere viden om børn og unges sociale, psykologiske og psykiatriske problemstillinger.

I antologien Ny udsathed i ungdomslivet (Gørlich m.fl., 2019) sættes der fokus på, hvordan man kan forstå ny udsathed og en øget oplevelse af psykisk mistrivsel blandt unge i dag. Denne optagethed af, at der er noget 'nyt' eller 'andet' på spil for ungdommen, synes også i særlig grad at træde frem i det kvalitative materiale fra de deltagende klubber. Her pointeres en oplevelse af, at mange af de unge i klubberne kommer med nye diagnoser og problemstillinger, som man ikke har viden om, og som man i det pædagogiske arbejde derfor godt kan komme til at føle sig magtesløs overfor. En pædagog udtrykker det således:

"Jeg er jo ikke terapeut, men jeg mangler viden om, hvordan jeg kan arbejde paedagogisk med alle disse nye diagnoser; fx selvskadende piger."

Analyserne af den kvalitative undersøgelse viser også, at pædagogernes ønsker til ny viden er mere fragmenteret og divergerende på tværs af de deltagende SFO'er og pædagoger. Denne pointe blev senere i dialogerne på workshoppene forstærket gennem fortællinger om børn med forskellige demografiske og sociokulturelle udgangspunkter

På baggrund af analyserne fra det kvalitative materiale udsprang otte tematikker, der blev efterspurgt mere viden om. Bevægelsen fra det kvalitative materiale til de otte tematikker blev foretaget gennem identificering og kodning af informanternes udsagn i de kvalitative interviews. Herefter blev der udsendt en spørgeskemaundersøgelse til 2500 af landets pædagoger ansat inden for det fritidspædagogiske område, hvor de blev bedt om at prioritere mellem følgende otte tematikker:

- Identitet, dannelse og ungdomskultur

- Udsathed og marginaliserede børn og unge 
- Almen fritidspædagogik

- Inkluderende fritidspædagogisk arbejde

- Science, udeliv og bæredygtighed

- Digitalisering, skærm, sociale medier

- Mangfoldighed, kultur og køn

- Kreativitet, æstetik og innovation.

Besvarelserne viste her en helt tydelig tendens til, at viden inden for det grundlæggende og almene fritidspædagogiske område blev fremhævet som et behov til fordel for mere specifikke faglige temaer. De fire øverste temaer; "Identitet, dannelse og ungdomskultur", "Udsathed og marginaliserede børn og unge", "Almen fritidspædagogik" og "Inkluderende fritidspædagogisk arbejde" trådte tydeligt frem som de fire højst prioriterede områder (Madsen og Stæhr, 2020). Hvorfor netop disse fire vidensfelter blev prioriteret frem for de fire andre, undersøgte vi yderligere på de afholdte workshops, hvor såvel pædagoger som ledere betonede, at disse fire tematikker er vidensområder, der vedrører fritidspædagogiske kerneopgaver. Både pædagoger og ledere gav udtryk for, at med nye generationer kommer nye problemstillinger og tematikker i børn og unges liv i spil; for eksempel ny udsathed, angst, diagnoser samt nye og mere udfoldede seksualitetsforståelser.

\section{Kvalitet i det fritidspcedagogiske arbejde?}

Forskellige både danske og svenske bidrag er kommet med bud på, hvad der er grundlæggende centrale begreber inden for det fritidspædagogiske felt (Højholt, Kousholt \& Stanek, 2014; Tofteng og Madsen, 2016; Ankerstjerne og Stæhr, 2018; Elvstrand og Lago, 2019). Disse bidrag bygger på undersøgelser af pædagogers arbejde og deres egne fortællinger om deres arbejde i henholdsvis skole og fritid og sætter fokus på, hvordan pædagogerne arbejder med børn og unge i skolen og/ eller i fritidsinstitutioner, hvilket giver os viden om, hvordan pædagoger anvender deres faglige ekspertise med børn og unge på tværs af institutionstyper.

Dog synes dette ikke at have bidraget til drøftelser af, om og hvordan vi kan tale om pædagogisk kvalitet på 6-18 års området, ligesom det ikke har bidraget til drøftelser af, hvad pædagogisk kvalitet i fritidsinstitutionerne er? Det har givetvis heller eller ikke været hensigten. Men spørgsmålet om pædagogisk kvalitet presser sig dog på, når vi læser på tværs af det empiriske materiale. I den indledende kvalitative undersøgelse anvendes kvalitetsbegrebet stort set ikke. Det gjorde det til gengæld på de afholdte workshops. Her formulerede pædagogerne det som et ønske om at blive opdateret med nyeste viden inden for det fritidspædagogisk arbejde. Efter flere år med fokus på læring og tilpasning af det fritidspædagogiske arbejde ind i skolen udtrykte pædagogerne et behov for at stå mere sikkert på deres fritidspædagogiske grundfaglighed ved at få udvidet, udbygget og opdateret denne. På workshoppene med lederne blev pædagogisk kvalitet formuleret i tilknytning til deres ønsker om, at videreuddannelsesforløb af medarbejdere skal 
sikre 'højere kvalitet' i det fritidspædagogiske arbejde. Fælles for dialogerne med henholdsvis pædagogerne og lederne var, at de pegede på, at der er forskellige forventninger til, hvornår det pædagogiske arbejde i fritidsinstitutionerne fungerer godt - altså hvad der er god kvalitet. Er det for eksempel, når institutionen leverer gode evalueringsresultater til forvaltningen, eller er det, når børnene fortæller, at de kommer for at hygge sig med deres venner i tillidsfulde rum, hvor man kan tale om ting, som er svære at tale om andre steder?

I bogen "Bedre begrundet praksis" argumenterer Rod og Kongsgaard for, at der i velfærdsprofessionelle institutioner er behov for fælles forståelser af, hvad der er god og dårlig kvalitet i det arbejde, der udføres i den konkrete institution (for eksempel i en fritidsinstitution) (Rod og Kongsgaard, 2018, s.18). Et sådan behov efterspørges ligeledes i vores empiriske materiale, som også vidner om, at der er forskellige forventninger til og opfattelser af, hvad der anses som 'god' og 'dårlig'. Rod og Kongsgaard opererer med to yderpoler eller faldgruber, som de ser tendens til, at man kan falde i, når der diskuteres kvalitet inden for velfærdsprofessionerne. De benævner de to yderpoler henholdsvis tavs viden-fælden på den ene side og manualiseringsfælden på den anden side (Rod og Kongsgaard, 2018, s.15). Tavs viden-fælden henviser til den individualiserede, intuitive og situationsbestemte praksis uden muligheder for generaliseringer fra en situation til en anden. Manualiseringsfælden henviser på den anden side til, at pædagogisk 'kvalitet handler om at følge bestemte manualer' (2018, s.15).

Med denne afgrænsning af kvalitet risikerer diskussionerne om pædagogisk kvalitet på den ene side at placere sig i en praksisforankret position uden pædagogfaglige begrundelser og på den anden side i en standardiseringstænkning, hvor det, der virker et sted, også må anses for at virke et andet sted. For at undgå at falde i en af de to yderpoler af, hvad der er god og dårlig kvalitet, kan man med fordel i stedet fastholde fokus på dialogiske og refleksive processer, der tager afsæt i situerede praksisser, og som har til hensigt at skabe bedre begrundet praksis. En sådan pointe kan synes banal, men ikke desto mindre understreger den betydningen af et situeret perspektiv i forhold til drøftelser om, hvad pædagogisk kvalitet kan være.

Med afsæt i Rod og Kongsgaard samt undersøgelsen, der ligger til grund for denne artikel, bliver det dermed også vanskeligt at præcisere, hvad kvalitet er, da det, der anses for at være pædagogisk kvalitet i én institution, divergerer fra, hvad der anses for at være pædagogisk kvalitet $\mathrm{i}$ en anden institution; netop fordi især børnenes og de unges socio-økonomiske vilkår, institutionernes demografi og organisatoriske forhold divergerer, hvorfor også det fagligt funderede pædagogiske arbejde vil være forskelligt. Dette blev bl.a. tydeligt på dialogværksteder med pædagogerne, hvor man i én institution oplevede, at det pædagogiske arbejde burde tage udgangspunkt i en mere specialpædagogisk faglighed, mens pædagogerne i en anden institution i højere grad havde fokus på social udsathed, og en tredje institution havde fokus på arbejdet med fællesskaber i børnenes frie tid. 
En kvalitetsdiskussion på det fritidspædagogiske område peger således ind i en modningsproces, som vi åbner for i denne artikel, og som både skal understøttes af og baseres på mere forskningsbaseret viden, flere praksisforankrede, faglige udviklingsprojekter i det fritidspædagogiske felt samt en prioritering og kvalificering af faglige drøftelser lokalt blandt de pædagogiske medarbejdere.

Dette perspektiv understreges særligt på workshoppene med de faglige organisationer, interesseorganisationer og Børne- og undervisningsministeriet, hvor kvalitetsbegrebet italesættes mere direkte med ønske om at blive klogere på, om det er muligt at afgrænse, hvad der karakteriserer det fritidspædagogiske arbejde, og hvorfor denne pædagogiske gren kan synes vigtig at styrke, når vi ser på de problemstillinger, der kendetegner børn og unges hverdagsliv anno 2020. Her rejses spørgsmålet om kvalitet netop ikke med et ønske om at få et måleredskab, der kan være med til at afdække eller standardisere, hvad der er god kvalitet. Det rejses i højere grad som et ønske om sammen med praksisfeltet at få arbejdet analytisk og refleksivt med at skabe fagligt funderet og reflekteret pædagogisk arbejde på 6-18 års området med udgangspunkt i situationsbunden kundskab, og som tager højde for børne- og ungegrupper afhængig af disses hverdagsliv, institutionsliv og interessefællesskaber.

Fraværet af politisk, økonomisk, forskningsmæssigt og uddannelsesmæssigt fokus på fritidspædagogisk faglighed rejser spørgsmålet om pædagogernes muligheder og betingelser for at udforske, udvikle og fagligt begrunde pædagogisk kvalitet i fritidsinstitutionerne. Fritidspædagogerne kan godt være dygtige praktikere (Rod og Kongsgaard, 2018), men hvilke muligheder har de for fagligt at begrunde deres pædagogiske arbejde og forholde sig refleksivt til egen praksis, hvis der ikke findes opdateret forskning på det fritidspædagogiske felt, og hvis pædagogerne på fritidsområdet kun kompetenceudvikles i forhold til deres arbejde i skolen?

Hvis vi med afsæt i Rod og Kongsgaard antager, at pædagogisk kvalitet handler om kontinuerligt at undersøge og forbedre praksis gennem fagligt funderede drøftelser og begrundelser af lokalt forankrede praksisser, placerer pædagogisk kvalitet i fritidsinstitutionerne sig et sted mellem, hvad der er den faglige viden, som for eksempel forskningsbaseret vidensproduktion, og den pædagogiske praksis. Det er i denne midterposition, at det bliver muligt at tale om pædagogisk kvalitet baseret på allerede eksisterende viden og på den konkrete, situerede og lokale kontekst.

Deltagerne i analyseworkshoppen pointerede, at pædagogisk kvalitet ikke skal gøres til et sandhedsbetinget neutralt og essentielt begreb, men til et situeret begreb, hvis primære præmis er, at pædagogisk arbejde er fagligt og professionelt begrundet. Og således vil pædagogisk kvalitet være dynamisk, matche det omgivende samfund og divergere fra institution til institution i en konstant faglig refleksion, hvor faglig viden og professionel erfaring tilsammen udvikler den faglige ekspertise på området. 


\section{Afrunding}

Artiklen har med udgangspunkt i en undersøgelse af kompetenceudviklingsbehov på det fritidspædagogiske område beskrevet den fritidspædagogiske faglige ekspertises bevægelse inden for de seneste år.

Undersøgelsen har vist, at der findes mange dygtige medarbejdere og ledere i fritidsinstitutionerne, som brænder for det fritidspædagogiske arbejde, men at de oplever at have vanskeligt ved at styrke og i bedste fald fastholde en stærk fritidspædagogisk ekspertise uden mødet med ny forskningsbaseret viden. Det empiriske materiale viser, at også når det gælder kompetenceudvikling, så oplever fritidspædagogerne, at tematikker og kurser, der styrker det pædagogiske arbejde i skolen, er blevet prioriteret på bekostning af kompetenceudvikling, der er rettet mod pædagogisk arbejde i fritidsinstitutionerne. Dette har haft en betydning for den faglige ekspertise i fritidsinstitutionerne, hvilket blandt andet kom til udtryk i materialet som et behov for at sætte fokus på drøftelser om pædagogisk kvalitet i fritidsinstitutionerne.

I artiklen åbner vi for spørgsmålet om, hvorvidt der inden for det fritidspædagogiske område er behov for en diskussion af pædagogisk kvalitet. I den forbindelse sættes der fokus på de pædagogiske medarbejderes kompetencer og muligheder for løbende at få deres pædagogiske faglighed skærpet og videreudviklet, så den passer til de foranderlige og aktuelle rammer og vilkår samt børn og unges interesser, spor og livsvilkår i dag. Skal medarbejdere og ledere opretholde fritidsinstitutionerne som stærke pædagogiske tilbud, hvor man på kvalificeret vis arbejder med børn og unges fællesskaber, dannelse, relationer og trivsel, er det afgørende, at de også står på en stærk faglighed inden for det fritidspædagogiske område (Ankerstjerne, 2014; Ankerstjerne og Stæhr, 2019; Madsen og Tofteng, 2017).

Hverken i undersøgelsen eller i denne artikel har vi tænkt i videnshierarkier mellem forskningsviden, professionsviden og praksisviden, men har gennem dialoger med pædagoger, ledere og organisationer udforsket og diskuteret pædagogisk ekspertise i fritidsinstitutioner, og har givet et bud på, hvordan vi med en kobling af et videnselement og et praksiselement (de dygtige professionelle) kan få den pædagogiske faglighed til at træde frem i fritidsinstitutionerne og dermed styrke den faglige ekspertise.

\section{Litteratur}

Ankerstjerne, T (2014). Didaktikken og pædagogens rolle i skolen. I Ritchie \& Tofteng (red.), Pcedagog $i$ skole og fritid (s. 117-135). Værløse: Billesø \& Baltzer

Ankerstjerne, T. og Stæhr, M.H. (2017). Faglighed i samarbejdet mellem lærere og pædagoger. I B. Dumstrei, \& T. H. Mortensen (red.), Grundfaglig viden om profession og samfund (s. 139-159). København: Akademisk Forlag.

Ankerstjerne, T. og Stæhr, M. (2018). Grundlag for pædagogfaglighed i fritid og skole. UVM og BUPL. Hentet fra https://bupl.dk/wp-content/uploads/2018/12/filer-grundlag_paedfaglighed_ fritid_skole-1.pdf 
UVM (2013). Aftaletekst. Aftale mellem regeringen (Socialdemokraterne, Radikale Venstre og Socialistisk Folkeparti), Venstre og Dansk Folkeparti om et fagligt løft af folkeskolen, UVM

Biesta, Gert J.J. (2013). Demokratilcering $i$ skole og samfund. Århus: Forlaget Klim

Biesta, Gert J.J. (2018). Undervisningens genopdagelse. Århus: Forlaget Klim

Brinkmann, Sven (2017). John Dewey og foellesskabelsens pæedagogik. Foellesskab i skolen. København: Akademisk forlag.

Broström, Stig (2015). Didaktik for skolepcedagoger. København: Hans Reitzels Forlag;

BUPL (2007). BUPL's Pædagogiske Profil. Hentet fra https://bupl.dk/wp-content/uploads/2018/01/ uncategorized-bupl_paedag_profil_07-3586.pdf

Elvstrand, H., Lago, L., Simonsson, M. (2019). Fritidshemmets möjligheter; Att arbeta fritidspedagogiskt. Lund: Studenterlitteraur.

Görlich, A., Pless, M., Katznelsen, N., Graversen, L. (2019). Ny udsathed i ungdomslivet; 11 forskere om den stigende mistrivsel blandt unge. København: Hans Reitzels Forlag

Husted, M., \& Tofteng, D. M. B. (2012). Arbejdsliv og aktionsforskning. I G. Duus, M. Husted, K. Kildedal, E. Larsen og D. Tofteng (red.) Aktionsforskning: en grundbog (s. 61 - 81). Frederiksberg: Samfundslitteratur.

Højholt, C., Kousholt, D., \& Stanek, A. H. (2014). Fritidspcedagogik, faglighed og foellesskaber. Frederikshavn: Dafolo.

Kamp, Mikkel (2019). Hver tredje er ikke med i skoleledelsen. Hentet fra https://bupl.dk/artikel/ hver-tredje-er-ikke-med-i-skoleledelsen/

Kamp, Mikkel (2019). Ledere presses ud. Hentet fra https://bupl.dk/artikel/ledere-presses-ud/

Klafki, Wolfgang (2001). Dannelsesteori og didaktik. Århus: Klim

Kongsgaard; Leif Tøfting og M.H. Rod (2018). Indledning. I Kongsgaard og Rod (red.) Bedre begrundet praksis. Frederiksberg: Samfundslitteratur.

Madsen, Lisbeth og Stæhr, M. (2020). Udvikling af fagspecifikke kurser for medarbejdere og ledere på det det fritidspædagogiske område. Hentet fra https://ufm.dk/uddannelse/videregaendeuddannelse/efter-og-videreuddannelse/veu-trepartsaftale/filer/19_12216-14-afsluttende-rapport-udvikling-af-fagspecifikke-kurser-1268877_1_1.pdf

Pedersen, R. og Feilberg, A. (2015). At lede efter læring på tværs af skole og fritid; pædagoger mellem organisatoriske fantasier og professionelle værdier. I Bjerg, H. og Vaaben, N. (red.), At lede efter loering; Ledelse og organiseringer i den reformerede skole (s. 169-187). Frederiksberg: Samfundslitteratur.

Petersen, Kirsten Elisa, L.H. Sørensen T.E.M. Sørensen og L. Ladefoged (2019). Fritids- og ungdomsklubbers betydning for børn og unges hverdagsliv og foellesskaber i udsatte boligområder. DPU, Aarhus Universitet. https://doi.org/10.7146/aul.350

Rambøll (2019). Evaluering af kompetenceudvikling af pædagoger i skolen - til gavn for børns læring og udvikling. Hentet fra https://www.kl.dk/media/21598/evaluering-af-kompetenceudvikling-af-paedagoger-i-skolen.pdf

Ringskou, L. og Gravesen, T.D. (2019). Hvad ved vi egentlig om skole- og fritidspædagoger? I Social Kritik nr. 160

Ringskou, L. og Gravesen, T.D. (2020). Med viden skal skole- og fritidspædagogik bygges. I Forskning $i$ Pcedagogers Profession og Uddannelse. Vol. 4, no. 1

Sauzet, Sofie (2019). Podagogers faglighed $i$ skolen; udspcendtheder i litteratur og praksis. Frederiksberg: Samfundslitteratur

Stanek, A.H. (2013). Fra fritidspædagog til skolepædagog. I Vera; vol.63

Stanek, A.H. (2019). Inkluderende fællesskaber i skole og SFO. I Ankerstjerne, T. (red.) Poedagogik mellem skole og fritid; Grundbog til poedagoguddannelsen (s. 109-125). Frederikshavn: Dafolo.

Toulmin, S. og G. Gustavsen (1996). Beyond Theory - Changing Organizations through Participation. London: John Benjamins Publishing Company.

Wiiborg, A. (2005). SFO og fritidshjem; pædagogisk fritid. I Børn \& unge no.19. 